\section{NEW ADDITIONS TO THE MANTID FAUNA (INSECTA: MANTODEA) OF ANDAMAN \& NICOBAR ISLANDS, INDIA}

\author{
P.M. Sureshan ${ }^{1}$, Md. Jafer Palot ${ }^{2}$ and \\ C. Radhakrishnan ${ }^{2}$
}

${ }^{1}$ Western Regional Station, Zoological Survey of India, Pune, Maharashtra 411044, India

${ }^{2}$ Western Ghats Field Research Station, Zoological Survey of India, Kozhikode, Kerala 673002, India

web supplement

The mantid fauna (Insecta: Mantodea) of Andaman \& Nicobar Islands is very poorly studied. According to Mukherjee et al. (1995), five species of mantids under four genera in two families are only known from these islands in scientific literature, out of the 162 species under 68 genera known from India.

A sample collection of entomofauna from the Andaman and Nicobar Islands included two specimens of mantids obtained from the locality Tirur $\left(11^{\circ} 42^{\prime} 35.5^{\prime \prime} \mathrm{N} \& 92^{\circ} 35^{\prime} 48.1^{\prime \prime E}\right)$, situated $30 \mathrm{~km}$ northwest of Port Blair. The specimens on identification, following Mukherjee et al. (1995) were distinguished belonging to two species, under two genera. On further analysis both the species turned out to be new additions to the mantid fauna so far reported from these islands. Besides the specimen data and identification details, a systematic list of the mantid species so far known from the Andaman and Nicobar Islands is also presented. The specimens are deposited at the Zoological Survey of India, Western Ghats Regional Station, Kozhikode.

\section{Acromantis montana Giglio-Tos, 1915}

1915. Acromantis montana Giglio-Tos. Bull. Mus. Torino 30(702): 7

Material examined: One male (collected under light), 27. iv. 2002, Tirur, Jarawa Reserve, South Andamans, India, coll. Md. Jafer Palot, ZSI/WGRS/IR/INV-1611

Measurements (in mm): Total body length male 23, pronotum 7 , forewing 19 .

Distribution: India: Arunachal Pradesh, Karnataka, Meghalaya, Tripura; Indonessia: Java.

Diagnosis: Tubercle above median ocellus small, spiniform; upper angle of frontal sclerite pointed; borders of pronotum with very small brownish tubercles (4 in prozona and 8 in metazona); coxa of fore legs with five small spines; border of femora without any hump, longer internal spines and discoidal spines brownish-black; costal area of forewing opaque, brownish-green, densely reticulate.

Remarks: Rane et al. (2002) reported the species from Karnataka.
Statilia maculata (Thunberg, 1784)

1784. Mantis maculata Thunberg. Nov. Ins. Spec. 3: 61. 1897. Statilia maculata Bolivar. Ann. Soc. Entomol. France, 66: 309.

Material examined: One male (collected under light), 27.iv.2002, Tirur, Jarawa Reserve, South Andamans, India, coll. Md. Jafer Palot, ZSI/WGRS/IR/INV-1612

Measurements (in mm.): Body length male 45, pronotum 15, forewing 29.

Distribution: India: Andhra Pradesh, Arunachal Pradesh, Assam, Bihar, Himachal Pradesh, Madhya Pradesh, Maharashtra, Meghalaya, Sikkim, Uttar Pradesh, West Bengal.

Diagnosis: Vertex almost black; forecoxa with seven triangular spines (first and last smaller) with few spinules and with internal black patch; femora with shiny yellow patch bordered anteriorly by a black line and a broad black patch below claw groove; costal area of forewing opaque, discoidal area almost hyaline with some opaque markings just below costal area.

\section{REFERENCES}

Mukherjee, T.K., A.K. Hazra and A.K. Ghosh (1995). The mantid fauna of India (Insecta: Mantodea) Oriental Insects 29: 185-358.

Rane, N., S. Ranade, H.V. Ghate and T.K. Mukherjee (2000). On the description of female of Acromantis montana Giglio-Tos from Kumta, Karnataka, Western Ghats (Mantodea: Hymenopodidae). Entomon 25(1): 61-62.

\section{ACKNOWLEDGEMENTS}

The authors are grateful to the Director, Zoological Survey of India, Kolkata and the Officer in Charge, Zoological Survey of India, Pune for facilities and encouragement. The authors also thank Dr. H.V. Ghate, Department of Zoology, Modern College, Pune for confirming the identity of the mantids.

Systematic list of mantids reported from Andaman \& Nicobar Islands

\section{Order: Mantodea}

Hymenopodidae: Acromantinae

Acromantis nicobarica Mukherjee, 1995.

1995. Acromantis nicobarica Mukherjee. Oriental Insects 29: 211.

Acromantis montana Giglio-Tos, 1915

1915. Acromantis montana Giglio-Tos. Bull. Mus. Torino 30 (702): 7

\section{Mantidae: Mantinae}

Hierodula (Hierodula) nicobarica Mukherjee, 1995.

1995. Hierodula (Hierodula) nicobarica Mukherjee. Oriental Insects 29: 211

Hierodula (Hierodula) tenuidentata Saussure, 1869

1869. Hierodula tenuidentata Saussure. M.H. Schweiz. Entomol. Ges., 3: 68. 1927. Hierodula (Hierodula) tenuidentata Giglio-Tos. Das Tierreich. 50: 444.

Mesopteryx robusta Wood -Mason, 1882.

1882. J. Asiatic Soc. Bengal. 51: 36

Tenodera superstitiosa (Fabricius, 1781)

1781. Mantis superstitiosa Fabricius. Spec. Ins. 1: 348.

1871. Tenodera superstitiosa Stal. Ofversk. Vetensk Akad. Forh. 28: 390.

Statilia maculata (Thunberg, 1784)

1784. Mantis maculata Thunberg. Nov. Ins. Spec., 3: 61

1897. Statilia maculata Bolivar. Ann. Soc. Entomol. France 66: 309 